\title{
Newspaper framing and climate change mitigation in Nigeria and Ghana
}

\author{
ljeoma D. Ajaero ${ }^{1,2}$ \& Luke I. Anorue ${ }^{1}$ \\ 1 Department of Mass Communication, University of Nigeria, Nsukka \\ ${ }^{2}$ Visiting Research Fellow, Department of Demography \& Population Studies, University of \\ Witwatersrand, Johannesburg, South Africa.
}

Email: ljeoma.ajaero@unn.edu.ng

\begin{abstract}
Background: The issue of climate change is a global one yet there exist little literature on African media coverage of climate change, even as developing nations are the worst hit by its effects.

Objectives: This study compared the influence of newspaper framing on climate change mitigation in Nigeria and Ghana. It also assessed challenges editors' face in reporting climate change.

Methods: The contents of eight national newspapers for both countries were analysed and the news editors of the sampled newspapers were interviewed.

Results: Findings showed that the issue of climate change was given less coverage and the dominant frame used in the Nigerian newspapers was the action frame, and environment frame for the Ghanaian newspapers, with floods as the prominent climate change issue reported in both countries. Factors identified include funding, the technicality of reporting climate change, none documentation and lack of expertise.
\end{abstract}

Conclusion: There is also need for editors to look for ways in making climate change reports more interesting.

Keywords: Mitigation, Climate Change, Newspaper Framing, Nigeria, Ghana,

\section{Introduction}

Climate change is one of the most serious challenges to society and has been regarded as a threat overshadowing other threats like war and terrorism (Hoijer, 20I0). It is a global phenomenon that has sprung up several concerns from world leaders and individuals alike. This is because it affects the environment, which in turn has impact on people and human activities. Climate change refers to variability in climate observed over a comparable period of time which is caused by two basic factors, which include natural processes (biogeographical) and human activities (anthropogenic) (Odjugo, 20l0). The annual average losses from just earthquakes, tsunamis, tropical cyclones and flooding count in the hundreds of billions of dollars, requiring an investment of US\$6 billion annually in disaster risk management alone (UNDP, n.d).

In 2015, the United Nations Framework Convention on Climate Change (UNFCCC) COP 2I, registered tremendous response from world leaders on combating climate change and its effects. The conference was held in Paris and the Paris agreement was adopted on 12th December, 2015, with 195 signatories and 168 parties. The Paris agreement establishes the main framework for cooperative action on climate change beyond 2020 and will replace the Kyoto Protocol. That same year, several countries came together to adopt the 2030 Agenda http://aps.journals.ac.za for Sustainable Development with its 17 Sustainable Development Goals (SDGs). These goals were adopted by world leaders (more than 150 countries) in September, 2015, with a pledge to 'mobilize efforts to end all forms of poverty, fight inequalities, and tackle climate change by 2030'. Among the identified goals, the 13 th SDG is specifically aimed at taking urgent action to combat climate change and its impacts.

Recently, the former President of Ghana, John Agyekum Kufor launched a Guidebook on climate change intended for journalists, editors, teachers and media trainers. He called climate change a 'global thief' and aver that the media have a critical role in helping people see that the world is 'under attack' (GNA, 20I8). In 2008, the BBC World Trust Service conducted a study in 10 African countries (Nigeria and Ghana inclusive) and found that the intensive media coverage and public awareness campaigns prevalent in much of the industrialized world have been largely absent in Africa, particularly outside major urban centers. This is echoed by Tagbo (2010) when she asserts that "broader public understanding of a range of climate change issues is required if Africa is to respond and adapt to climate change' (p.I6).

According to Mercado (20/2) 'the media play an essential role in the construction of social reality and consequently knowledge of what is reported in the 
media is essential to understanding social attitudes towards significant issues such as climate change' (p. 193). Ukonu (20I2) contends that media portrayal of climate change can help to shape public perception and, thereby, influence how the fight against climate change is converted into action and policy. The media can make valuable contributions towards the implementation of the SDGs by creating awareness about the development agenda, challenging and stimulating debates on solutions in tackling issues raised by these goals (Nashuuta, 2016).

Bowe, Oshita, Terracina-Hartman and Chao (20I2) argued that 'the issue of climate change provides an instructive case study for framing researchers because of its tremendous complexity, transcending economic, political, scientific, and social boundaries across cultures (p.I59). Framing is an important and necessary tool employed by journalists to break down and reduce the complexity of an issue.

Nigeria and Ghana signed the United Nations Framework Convention on Climate Change (UNFCCC) in 1992. While Nigeria adopted the National Adaptation Strategy and Plan of Action on Climate change, Ghana came up with the Renewable Energy Act National Action Plan on Climate Change. These policies were adopted to help citizens mitigate and adapt to the effect of climate change and also achieve the SDGs of the United Nations. Nigeria and Ghana were chosen for this study to reflect the framing of climate change reports in the Anglophone West African region. Also, both countries have similar climate and experience extreme weather events as a result of climate change.

While several researchers have studied the frames employed by the media in reporting climate change (Nwabueze and Egbra, 2016; Asplund et al, 2012; Tagbo, 2010; Boykoff, 2009; Cramer, 2008), there is a dearth of studies on climate change frames in the West Africa media. Although Nwabueze et. al (2016) studied the Nigerian and Ghanaian newspapers framing of climate change, they however did not examine challenges editors' face in reporting climate change, a gap this study seeks to fill.

Subsequently, this comparative study investigates the frames employed by the Nigerian and Ghanaian newspapers in their reportage of climate change. It also assessed challenges editors' face in reporting climate change. To this end, this study is aimed at (i) identifying the frequency of coverage and story genres used (ii) ascertain the sources of news story for climate change reports in the selected dailies; (iii) identify the frames employed by the Nigerian and Ghanaian papers in their reportage of climate change (iv)assess challenges editors' face in reporting climate change.

Literature review and theoretical framework
Communication of climate change from scientists and policy-makers to the public via the mass media has been a subject of major interest because of its implications from creating national variations in public understanding of the global environmental issue (Bilett, 20I0). The BBC World Trust Service (2008) study identified the media and schools as African citizens' major source of information. One might argue that the media only mirrors what the scientists and policy makers are saying about climate change but Boykoff \& Boykoff (2007) avers that mass media coverage of climate change is not simply a random amalgam of newspaper articles and television segments; rather it is a social relationship between scientists, policy actors and the public that is mediated by such news packages.

The science of climate change is full of uncertainty, but the greater vulnerability of poor countries to the impacts of climate change is one aspect that is widely acknowledged (Doulton \& Brown, 2009). From prolonged droughts to melting glacier to heavy flooding and unpredictable weather patterns, it can be argued that climate changes are already wreaking lives in Africa (Tagbo, 20l0, p.II). Climate change adaptation is ultimately a socioinstitutional process, requiring knowledge of risks perceptions, who or what needs to adapt, and how (McEvoy, Funfgeld and Bosomworth, 20I3). This is where the media comes in with its information and educational role. The media can influence people's perception of climate change by the way they frame these issues to the public.

Framing is a critical activity in the construction of social reality because it helps shape the perspectives through which people see the world (Hallahan, 1999, 207). Scheufele and Tewksbury (2007) is of the opinion that framing is based on the assumption that how an issue is characterized in news reports can have an influence on how it is understood by the audience'. 'Framing is a way of giving some overall interpretation to isolated items of fact' (McQuail 2005, p.379). Nwabueze and Egbra (2016) states that frames tell why an issue is a problem, the causes, and the solutions. That is to say that through the use of frames by the media, several complex events can be understood by people in the society.

The proponent of framing theory, according to Schuefele and Tewksbury (2007), includes the sociologist, Goffman (1974), the economist and the psychologists, Kahneman and Tversky (1979, 1984), the cognitive Linguists, Lakoff (2004) and communicators Entman (199I) and lyengar (199I). McQuail (2005) affirm that 'the idea of framing ... is an attractive one and provides a strong hypothesis that audience will be guided by journalistic frames in what it learns. They will also learn the frames 
themselves' (p.5II). Baran \& Davis (2006) defined framing theory as 'an assertion that people use expectations of the social world to make sense of that social world' (p.285) Kalvas et al (20I I) assert that framing theory 'describes how the complexity of issues that are difficult to understand can be reduced'. Entman (1993) as cited in Schuefele (1999) explains that "framing theory purports that the media focuses the attention of the audience on a particular news event and then place them within a specific field of meaning".

Littlejohn and Foss (2008) aver that 'media framing, then, is not trivial but is critical to producing the world as we know it'. This is to say that the media do not only set agendas, but also influence people's thoughts and actions in so many ways. That was why DeVreese (2005) asserts that 'framing must be perceived as a process in which frame-building happens first, followed by frame-setting, and this process has its consequences as well'.

The notion of framing has gained momentum in the communication disciplines, giving guidance to both investigations of media content and to studies of the relationship between media and public opinion (DeVresse, 2005) and as such, researches has been conducted globally on media coverage and framing of climate change. Studies in the United States include (Boykoff and Boykoff, 2004; Antilla,2005; Weathers and Kendall, 2015; Boykoff and Boykoff, 2007; Boykoff, 2007); Canada (Young and Dugas, 20I2); Italy (De Blasio and Sorice (20I3); India (Billett, 20I0; Boykoff, 20I0) Peru (Takahashi, 20I0), New Zealand (Chetty, Devadas and Fleming, 2015), Australia (McEvoy, Funfgeld and Bosomworth, 2013), Argentina (Mercado, 20I2), United Kingdom (Doulton and Brown (2009) and Sweden (Asplund, 20I4; Shehata and Hopmann, 20I2).

The African media have also received considerable research from several communication scholars who sought to investigate their coverage and framing of climate change. These studies include Cramer (2008), who assessed newspaper framing of climate change in South Africa; Tagbo (2010) did a comparative study of Nigerian and South African newspaper coverage of climate change; Batta, Ashong and Bashir (20l3) and Ukonu et al. (20l2) investigated press coverage of climate change issues in Nigeria while Nwabueze and Egbra (2016), assessed Newspaper framing of climate change in Nigeria and Ghana. Irrespective of these, it has been revealed that the Nigerian mass media do not give significant coverage and provide effective awareness on climate change issues even as they fail to offer adequate explanations to environmental issues in general (Batta, Ashong and Bashir, 2013; Moeti,
Maraisana and Marou, 2008; Ukonu, Akpan and Anorue, 2012; Ajaero, Okoro and Ajaero, 20l6).

The issue of climate change cuts across geographical boundaries and affects people's lives and livelihoods. The economy of a country is also dependent on its ability to mitigate and adapt to the effect of climate change. Nigeria and Ghana are developing nations in West Africa and have experienced their own share of environmental disasters that has impacted negatively on Agriculture, health and the economy. There exists little research on framing of climate change in Africa and this call for more research into African media coverage of a global issue like climate change. Using Nigeria and Ghana as a case study for West Africa newspaper framing of climate change, this work will comparatively analyze frames used by the newspapers in both countries in reporting climate change and also discuss the challenges these editors face in covering climate change.

\section{Data and methods}

This study made use of content analysis and interview survey as the methods of data collection. Kerlinger (2000) as cited in Wilmer and Dominick (20II) defined content analysis as a 'method of studying and analyzing communication in a systematic, objective, and quantitative manner for the purpose of measuring variables'(p.I56). The variables measured in this study are the number of times the selected dailies reported climate change, the story genres used (Straight news, Features, editorials, opinion articles, letter-to-the-editor and cartoons), and the frames (environment, political, scientific, human interest, economic consequences, action, warning and miscellaneous) employed in reporting climate change.

A total of eight national newspapers (four Nigerian and four Ghanaian) were content analyzed. The newspapers were purposively selected to form the sample for this study and they are: Daily Sun, Vanguard, The Guardian and The Nation (for Nigeria); Daily Graphic, Daily Guide, The Ghanaian Times and Ghanaian Chronicles (for Ghana). These newspapers were chosen because they are widely circulated, cover diverse issues on a daily basis and are national newspapers. News editors of the selected dailies were interviewed to identify challenges that influence their reportage of climate change issues. The researchers called ahead of time and were invited by the editors to conduct the interviews. They all agreed to be interviewed and the session was recorded.

The content of the selected dailies from January 20I5-December, 2016 (2 years) was analyzed. This period covers the 2015 Paris conference (COP 2I) 
and the 2016 Marrakech conference (COP 22). Also, the SDGs were adopted in 2015 as a 'universal call to action to end poverty, protect the planet and ensure that all people enjoy peace and prosperity'. The continuous week formula was employed in choosing 2weeks (Monday-Friday) each to be studied for the years (that is 2015 and 2016). Using the lottery method of sampling, the weeks that make up 2015 and 2016 were each assigned a unique number and then put in two different bowls and shaken. The researchers then picked the weeks that were studied.

Table I: Distribution of weeks

\begin{tabular}{|l|l|l|}
\hline Newspapers & Weeks (20I5) & Weeks (20I6) \\
\hline Daily Sun & Week I5-16 & Week 33-34 \\
\hline Vanguard & Week 5-6 & Week 42-43 \\
\hline The Guardian & Week 27-28 & Week 50-5I \\
\hline The Nation & Week 37-38 & Week I6-I7 \\
\hline Daily Graphic & Week 5I-52 & Week II-12 \\
\hline Daily Guide & Week 3I-32 & Week I-2 \\
\hline Ghanaian Times & Week 45-46 & Week I8-19 \\
\hline Ghanaian Chronicle & Week 22-23 & Week 37-38 \\
\hline
\end{tabular}

NB: Weekend editions were omitted because Ghanaian newspapers do not have weekend editions

Therefore, the total number of edition of the eight newspapers that were studied was $160(n=160)$. The weekend editions of the selected dailies were excluded as Ghanaian newspapers do not have weekend editions.

The instruments for data collection for this study were the code sheet, and interview guide. For the content analysis, the Hosti's formula was used to calculate the intercoder reliability for this study. The formula is:

$$
\text { Reliability }=\frac{2 M}{N_{1}+N_{2}}
$$

Where $M$ is the number of coding decisions on which two coders agree, and $\mathrm{NI}$ and N2 are the total number of coding decisions by the first and second coder.

Based on the frames used by Cramer (2008) and Nwabueze and Egbra (2016), the following eight frames were adjudged suitable for this work:

I. Environment frames: - The environment frame is defined as articles or news stories whose major focus is on the effects and impact of climate change on our natural environment.

II. Scientific Frame: The scientific frame incorporates stories that are technical and filled with scientific jargons.

III. Economic loss/consequence: - These include stories on the economic effects of climate change in terms of loss of property, collapse of bridges and destruction of homes and businesses.

IV. Action frame: - This frame incorporates stories that deal with a call for urgent action to combat and mitigate the effects of climate change.
V. Political frame: - This frame incorporates stories whose major focus is on political developments and government intervention on climate change.

VI. Human interest frame:- For the purpose of this work, the human interest frame was seen as any story that emphasized on the effects climate change has on the people, putting into consideration their feelings about the issue.

VII. Warning frames:-This frame includes news reports that have a warning tone alerting people to the effects of climate change.

VIII. Miscellaneous: - This will incorporate other subject areas like weather, conflict, food security and health.

The data for this study was analyzed quantitatively, using Excel, and qualitatively. In presenting the result gotten from the code sheet, simple percentages and tables were used. The results from the interview were discussed in the work, in addition to using verbatim quotes to explain the challenges that editors' face in reporting climate change.

\section{Results}

Frequency of coverage and story genres

A total of 76 stories were gotten from the 160 editions studied $(n=160)$, with The GhanaianTimes having the highest number of climate change stories (I8\%), and Daily Guide having the least number of stories. Nigerian newspapers had a total of 40 $(52.6 \%)$ stories while Ghanaian newspapers had 36 (47.4\%) stories. 
Table 2: Frequency of coverage $(n=160)$

\begin{tabular}{|c|c|c|c|c|c|}
\hline \multicolumn{3}{|l|}{ NIGERIA } & \multicolumn{3}{|l|}{ GHANA } \\
\hline Newspapers & Frequency & Percentage & Newspapers & Frequency & Percentage \\
\hline Daily Sun & 10 & $25 \%$ & Daily Graphic & 10 & $27.8 \%$ \\
\hline Vanguard & 8 & $20 \%$ & Daily Guide & 5 & $13.9 \%$ \\
\hline The Guardian & 13 & $32.5 \%$ & The Ghanaian Times & 14 & $38.9 \%$ \\
\hline The Nation & 9 & $22.5 \%$ & The Chronicle & 7 & $19.4 \%$ \\
\hline TOTAL & 40 & $100 \%$ & & 36 & $100 \%$ \\
\hline
\end{tabular}

Also, the story genre that was most used was the straight news format with Ghana having 26 stories and Nigeria 21. However, Nigerian newspapers had 17 features stories while the Ghanaian newspapers had just 5. Both country newspapers had equal number of opinion articles (2), with Ghanaian newspapers publishing two editorials and one letterto-the-editor on climate change.

Table 3: Story genres

\begin{tabular}{|c|c|c|c|c|c|c|c|c|c|}
\hline $\begin{array}{l}\text { Story } \\
\text { Genres }\end{array}$ & D S & $\mathrm{V}$ & T G & $\mathrm{TN}$ & $\mathrm{DGr}$ & $\mathrm{DGu}$ & TGT & GC & Total \\
\hline $\begin{array}{l}\text { Straight } \\
\text { News }\end{array}$ & 5 & 4 & 7 & 5 & 7 & 4 & 12 & 3 & 47 \\
\hline Features & 5 & 4 & 4 & 4 & I & - & 2 & 2 & 22 \\
\hline Editorials & - & - & - & - & - & - & - & 2 & 2 \\
\hline $\begin{array}{l}\text { Opinion } \\
\text { articles }\end{array}$ & - & - & 2 & - & 2 & - & - & - & 4 \\
\hline $\begin{array}{l}\text { Letters- } \\
\text { to-the- } \\
\text { editors }\end{array}$ & - & - & - & - & - & I & - & - & I \\
\hline Cartoons & - & - & - & - & - & - & - & - & - \\
\hline Total & $0^{1}$ & 8 & 13 & 9 & 10 & 5 & 14 & 7 & 76 \\
\hline
\end{tabular}

Note: DS-Daily Sun; V-Vanguard; TG-The Guardian; TN-The Nation; DGr-Daily Graphic; DGu-Daily Guide; TGTThe Ghanaian Times; GC-Ghanaian Chronicles

\section{Story sources}

The major source of stories on climate change in Nigeria (78\%) and Ghana $(59.50 \%)$ were reporters. However, $24.30 \%$ of stories were sourced from News Agencies in Ghana. Nigerian newspapers (14.6\%) had the highest number of stories without a known source while the Ghanaian newspapers (18.10\%) sourced some of its stories on climate change from Government officials. The Guardian newspaper of Nigeria and Daily Graphic of Ghana had a story each written with two sources (Reporter and agency report). 


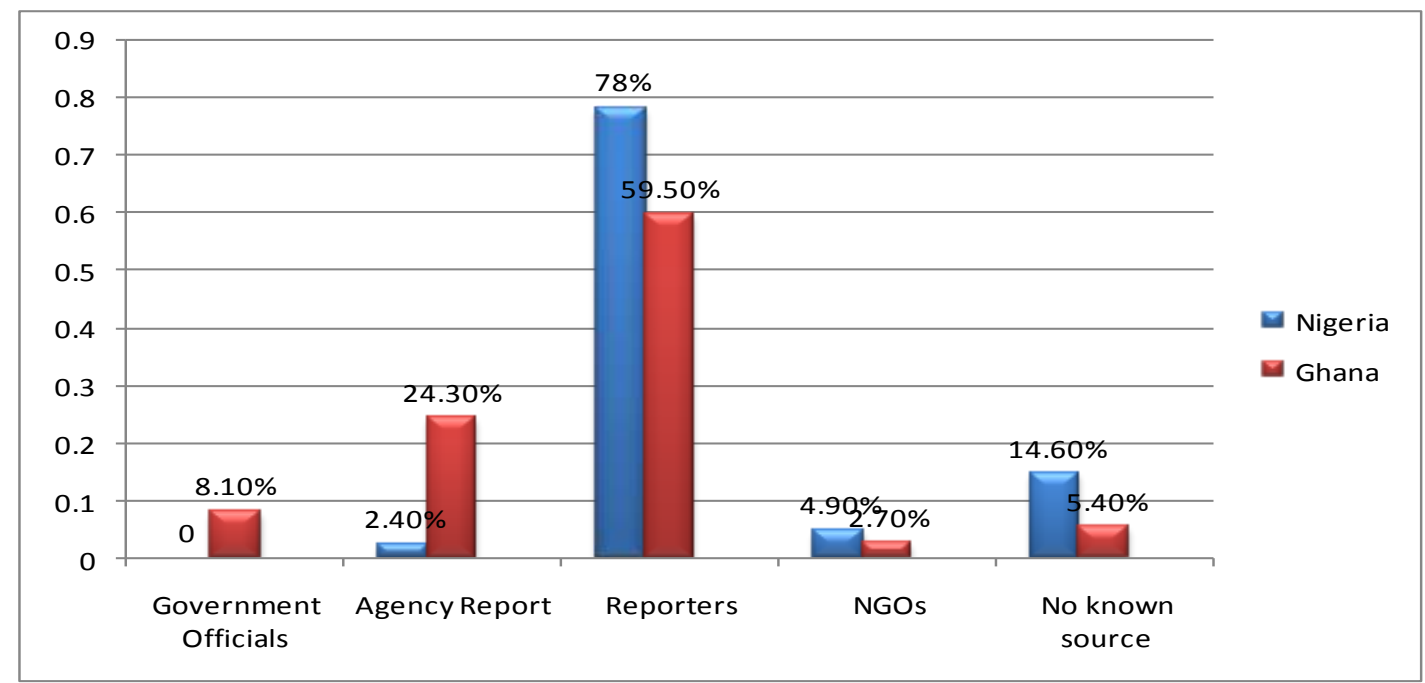

Figure I: Sources of news stories on climate change in the Nigerian and Ghanaian newspapers NB: *Some stories have more than one source

\section{Frames}

However, for the Ghanaian newspaper, the environment frame (20) came first, followed closely by the Action (17) and Human interest (17) frames. The Action frame was the most dominant (27) in the Nigerian newspapers, followed by the Human interest frame (16).

Table 4: Frames used by the Nigerian newspapers

\begin{tabular}{|ccccccc|}
\hline Frames & Daily Sun & Vanguard & The Guardian & The Nation & Total \\
\hline Environment & 2 & 2 & 4 & 2 & 10 \\
\hline Political & 2 & 1 & 1 & 2 & 6 \\
\hline Scientific & - & - & - & 1 & 1 \\
\hline $\begin{array}{c}\text { Human } \\
\text { Impact }\end{array}$ & 6 & 4 & 2 & 1 & 10 \\
\hline $\begin{array}{c}\text { Economic } \\
\text { Consequences }\end{array}$ & $\mathrm{I}$ & 3 & 5 & 4 & 27 \\
\hline Action & 7 & 5 & 11 & 3 & 8 \\
\hline Warning & 4 & - & 1 & - & 1 \\
\hline Miscellaneous & - & - & 1 & 17 & 79 \\
\hline Total & 22 & 15 & 25 & & \\
\hline
\end{tabular}

Table 5: Frames employed by the Ghanaian newspapers

\begin{tabular}{|cccccc|}
\hline Frames & $\begin{array}{c}\text { Daily } \\
\text { Graphic }\end{array}$ & Daily Guide & $\begin{array}{c}\text { The Ghanaian } \\
\text { Times }\end{array}$ & $\begin{array}{l}\text { Ghanaian } \\
\text { Chronicles }\end{array}$ & Total \\
\hline Environment & 3 & 5 & 6 & 6 & 20 \\
\hline Political & 1 & 2 & 8 & 2 & 13 \\
\hline Scientific & - & - & - & - & - \\
\hline $\begin{array}{c}\text { Human } \\
\text { Impact }\end{array}$ & 3 & 3 & 5 & 6 & 17 \\
\hline $\begin{array}{c}\text { Economic } \\
\text { Consequences }\end{array}$ & 2 & 1 & 3 & 5 & 11 \\
\hline Action & 3 & 1 & 9 & 4 & - \\
\hline Warning & - & - & - & - & 6 \\
\hline Miscellaneous & 5 & - & 1 & - & 84 \\
\hline Total & 17 & 12 & 32 & 24 & 7 \\
\hline
\end{tabular}




\section{Challenges identified by editors}

Editors of the sampled dailies identified about six challenges that influence their reportage of climate change as:

\section{Funding:}

Editors of the sample dailies identified funding as one of the factors that hinder coverage of climate change issue. Most times, they cannot attend workshops or seminars outside the country on climate change due to lack of funds

The technicality in reporting climate change: The editors complained that the language of climate change is too technical and scientific and this makes it difficult to communicate it to ordinary citizens.

The only problem is the language of climate change. Sometimes even the professionals will not know how to break it down for you-Edmund Smith Asante, Environmental reporter, Daily Graphic

\section{Lack of data/expertise:}

The issue of data was equally identified as editors complained that there are few or no documents to use when writing stories on climate change. The editor of The Guardian newspaper in Nigeria complained that there is a lethargy in giving information and sometimes, they are required to produce clearance while other times, the document does not exist.

Journalists are not trained on environmental reporting or climate change reporting in Journalism school and this is a major challenge identified by the editors

\section{Market mechanism:}

"I believe climate change is a major issue as people are at risks, but we are driven by the market. If you put climate change as your main story, your papers will be returned. Bad news sells so we use bad news to make money. We wait until major disaster occurs like floods before we report it" - Fortune Alimi, Editor, Daily Guide "Newspaper is business. There must be a rich balance between newspaper and business. Environment is a very narrow area in the industry. If you are talking about broader areas like politics and sports that are more of human interest". -Cosmas Omegoh, Assistant Features Editor, Daily Sun.

"We are waiting for disaster; we are waiting for major catastrophe. That will sell! Let the sea start taking our towns, our villages along the coast, that is when we get up and publish"-Dave Agbenu, Editor, Ghanaian Times
Inaccurate weather report:

The editors in Ghana lamented that they do not get accurate weather report. No accurate report on the weather unlike developed climes.

\section{Political system:}

"The political system is the worst enemy. Our chiefs are bribed when there is environmental degradation and these chiefs make things difficult for the reporter because you have to pass through them since you do not know the terrain"-Ebo Quansah, Editor, Ghanaian Chronicle.

"We are in a political season, so politics is now holding sway above other things. Unfortunately, the Environment and Sanitation page is on hold at the moment because it has been subsumed with a lot of political stories"- Edmund Smith Asante, Environmental reporter, Daily Graphic.

However, the editors in Nigeria pointed out two challenges that hinder adequate reportage of climate change in the country, which was not identified by the Ghanaian editors. They are insecurity in Nigeria and the fact that advertisers are considered when writing stories on climate change. In the same vein, the editors of the sampled Ghanaian newspapers identified the absence of an environment beat as a big challenge. Out of the four newspapers sampled, only one, Daily Graphic, had an environment page.

\section{Discussion}

This study sought to investigate comparatively Nigerian and Ghanaian newspapers framing of climate change mitigation and also identify challenges editors' face in reporting climate change. Climate change is a global issue and should as well attract adequate coverage especially in Africa. This is not so as only 76 stories emerged from the 160 editions studied. This finding collaborated Nwabueze and Egbra's (2016) study that concluded that the Nigerian and Ghanaian media did not give significant coverage of climate change issues. This can be attributed to funding and the issue of climate change stories as 'hard-sell' (Tagbo, 20l0). Nigeria and Ghana are developing nations with sparse resources at their disposal.

The most used story genre was the straight news format which indicates that the media only reports issues and disasters that occur as a result of climate change. The Ghanaian newspaper had more straight news stories with little features story implying that the frames were episodic. However, the Nigerian newspaper had more feature stories on the issue of climate change, especially floods, implying that they made use of thematic frames. However, the editors of the sampled dailies agreed that they wait for disasters to occur before they report issues and when they do, it is mostly in the straight news 
format. This finding is in line with Ajaero et al. (2016) study that concluded that the 2012 Nigerian floods reports were event centered. Only on few occasions did they do a feature story. The action frame was the most used by the Nigerian newspapers as reports from the newspapers called on people to take action to tackle climate change, while Ghana made use of the environment frame. The dominant climate change issue reported was flooding which is the most common natural disaster in these countries. In as much as it is advocated that people take action to combat the issue of climate change, it is still not the best frame for the Nigerian newspapers. The use of the human interest frame will go a long way in personalizing the effects of climate change and x-ray the roles people play in enhancing its effects, thereby creating more awareness for adequate mitigation of its impacts. The Ghanaian newspapers' use of the environment frame only portrays climate change as a purely environmental issue, which will affect peoples' reaction to mitigating its effects. Floods was the most discussed climate change issue but if the Ghanaian newspapers are only interested in reporting the devastating effects of the floods on the environment, people are likely to think that it is a purely environmental issue that cannot be mitigated. On the other hand, the human interest frame will show the sufferings and the impact of these disasters on the people.

The attitude of editors in both country towards climate change stories makes it impossible to create adequate awareness on the subject. Since climate change does not sell their paper, they tend to forfeit stories on climate change for others like politics and sports.

Climate is actually the lowest policy priority of Ghanaians-it comes as number 16 of 16 topicsLomborg (2015), Daily Graphic, December 10.

In 2016, because Ghana was preparing for their Presidential elections, the Environment \& Sanitation page of the Daily Graphic was put on hold for over a year to accommodate political stories. The Environmental reporter for the Daily Graphic, Mr. Edmund Smith Asante attributed it to the fact that 'we have not gotten to the point where climate change story is very important'. Also, the editors agreed that there is need to sensitize the people on climate change and this can be linked to the dominance of the action frame in the sampled dailies

Climate change is no longer a distant subject matter for scientists but a daily reality for citizens- Bentil (20I5), Daily Graphic, December 18.

The technicality of climate change reports was identified by editors as one of the factors that hinder appropriate climate change stories. This is in line with Boykoff and Boykoff (2007) assertion that scientific 4235 findings constitute a specialized mode of knowledge that is almost always packaged in professional language' (p.I 192). The issue of language used was raised by BBC (2008) and CRED (2009) in their research. According to the BBC (2008), 'climate change terminology is poorly understood and does not have standard translations in African languages'. Subsequently, CRED (2009) research shows that 'in order for climate change science information to be fully absorbed by audiences, it must be actively communicated with appropriate language, metaphor, and analogy; combined with narrative story telling; made vivid through visual imagery and experiential scenarios; balanced with scientific information; and delivered by trusted messenger in group settings' (p.2).

\section{Climate change mitigation in Nigeria and Ghana}

For Africa, the mitigation of climate change is necessary and there is a need for urgent action. As developing countries in West Africa, Nigeria and Ghana can lead the way for Africa's contribution to the global climate change debate. The SDGs are important targets set out to be achieved by world leaders by the year 2030. With 17 goals, the SDGs are global targets that will help in improving peoples' lives and livelihoods. The 13th goal is specifically aimed at taking 'urgent' action in tackling climate change and its impacts. This study is anchored on the assumption that the media as change agents in society are an indispensible institution in the actualization of this goal. This they do by creating awareness and educating the people on how to mitigate and adapt to the effects of climate change. Climate change has been said to be human induced and as such, people need to be aware that their actions cause climate change and also look for possible solutions to tackling it.

Nigeria and Ghana are West African countries that are least emitter of the greenhouse gases but are the most affected. It is therefore expected that the media in Africa will be agog with reports on climate change and how the actions of the industrialized nations are affecting our environment. They should serve as a platform where African voices will be heard in the global discourse but that is not the case. The coverage of climate change in the Nigerian and Ghanaian newspaper are grossly inadequate. So many issues came up in 2015 and 2016 but surprisingly, they were absent in the media. Even during the time when the UNFCCC (COP2I) in Marrakech, Morocco was on, the reports did not peak and the media did not even discuss the implications of the decisions taken at the conference.

The human interest angle to climate change stories should be reported more so that individuals 
will understand these stories better. This is in line with Nasuuta (2016) observation when he suggests that the media in Africa have an important role to play in the implementation of the SDGs by writing human interest stories that influence opinion, policy and individual actions.

The successful adaptation and mitigation to climate change by Nigeria and Ghana will go a long way in achieving other SDGs, which will in turn bring sustainable development by 2030 . This statement is further collaborated by CRED (2009) when they assert that 'the ultimate solutions to climate change are workable, cost-effective technologies which permit society to improve living standards while limiting and adapting to changes in the climate'. An effective adaptation and mitigation strategy to climate change will help achieve SDGs 2, 3, 6, and 7.

SDG 2 advocates for zero hunger by 2030 and climate change has been known to affect agricultural produce and production. This is because as the planet gets warmer, rainfall patterns shift and this leads to extreme weather events like floods, drought, etc. 'Climate change is therefore a factor in determining the ability of a people and their government to respect, protect and fulfill the right to food and freedom from hunger' (CSJ, 2016, p.I). If the media creates more awareness and help shape people's perception on climate change, then the issue of hunger will be tackled.

In the same way, good health and well-being (SDG 3 ) and clean water and sanitation (SDG 6) are still dependent on climate change. According to WHO (20I5), 'climate change threatens to exacerbate today's health problems-deaths from extreme weather events, cardiovascular and respiratory diseases, infectious diseases and malnutrition-whilst undermining water and food supplies, infrastructure, health systems and social protection systems'. Climate change causes extreme weather conditions and these events affect our lives and livelihoods. When floods occur, peoples' homes and properties are submerged in water and some persons, who have nowhere to go, actually stay put. As such, the water is polluted and this can cause several diseases.

One of the adaptive measures advocated include clean energy. This is contained in SDG 7 If a country can provide affordable and clean energy for its citizens, then this will reduce the amount of $\mathrm{CO}_{2}$ gas that is released into the atmosphere, thereby helping to mitigate the effect of climate change.

\section{Conclusion}

Climate change is a serious global issue that has tremendous impact on people; therefore, there is need for urgent action to combat it. The threat of climate change was identified by leaders in 2015 when they adopted the SDGs with 17 goals. This study investigated newspaper framing and climate change mitigation in Nigeria and Ghana and also identified challenges that the editors of these various newspapers face in reporting climate change.

The implications of this study to achieving the SDGs by 2030, especially in West Africa is that African countries will not meet up with the rest of the world if the challenges observed by these editors are not addressed. The government of both country needs to sit up and come up with policies that will be actualized. If the government had been executing projects as outlined in their reports, then there will be many reports on that and that will go a long way in sensitizing the people, thereby causing attitudinal change.

There is also need for editors to look for ways in making climate change reports more interesting. This can be done by framing stories more to reflect the human angle. When one reads a story about the life and suffering of a particular person as a result of climate change, then the person can begin to relate with the story and then put into practice what has been taught. People can be asked to 'calculate their carbon credit'. This is a model where people are taught about their activities that cause climate change and then are asked to calculate their carbon credit according to their level of emission. That way, they become conscious of their actions and inactions.

However, this study cannot be used to assess awareness level or perception of Nigerians and Ghanaians on climate change. This will require an audience study that will be conducted using a questionnaire.

\section{References}

Ajaero, I. D., Okoro, N. M. \& Ajaero, C. K. (20I6). Perception of and attitude towards mass media reportage of the 2012 flood in rural Nigeria. SageOpen, [Online] I-8. Available from doi: I0.1 I 77/2I 582440I 6666887 [Accessed I I th June, 2017]

Antilla, L. (2005). Climate of skepticism: US newspaper coverage of the science of climate change. Global Environmental Change, I5(I), 338352

Asplund, T. (20I4). Climate change frames and frame formation: An analysis of climate change communication in the Swedish Agricultural sector. Linkoping studies in Arts and Science, No. 619.

Asplund, T., Hjerpe, M. \& Wibeck, V. (20I2). Framing and Coverage of Climate Change in Swedish Specialized Farming Magazines. Springer Verlag. [Online] Available from http://dx.doi.org/l0.1007/s I 0584-0 I 2-0535-0.

[Assessed I I th January, 20 I3] 
BBC World Service Trust (2008). Nigeria Talks Climate: The Public Understanding of Climate Change. Africa Talks Climate-Research report Nigeria. [Online] Available from www.africatalksclimate.com [Assessed 2nd June, 2014]

Baran, S. J. \& Davis, D. K. (2006). Mass Communication Theory: Foundations, Ferment and Future 4th Edition. USA. Thomson Wadsworth.

Batta, H. E., Ashong, A. C. \&Bashir, A. S. (20/3). Press coverage of climate change issues in Nigeria and the implication for public participation opportunities. Journal of sustainable development. 6(I), 56-69.

Bentil, N. L. (2015). Ghana needs \$23bn for climate change adaptation, mitigation. Daily Graphic, December 18, p. 45

Bilett, S. (2010). Dividing Climate Change: Global warming in the Indian mass media. Climatic Change, [Online] 99(I), I-I6.Available from doi: 10.1007/s 10584-009-9605-3 [Accessed 10th January, 20I7]

Bowe, B. J., Oshita, T., Terracina-Hartman, C. \& Chao, W. (20I2). Framing of climate change in newspaper coverage of the East Anglia e-mail scandal. Public Understanding of Science, [Online] 23(2), 157-169. Available from doi: 10.1177/09636625/2449949 [Accessed 12th January, 2017].

Boykoff, M. T., McNatt, M. M. \& Goodman, M. K. (20I5). Communicating in the anthropocene: The cultural politics of climate change news coverage around the world. In Hansen, A. \& Cox, A. (Eds). The Routledge Handbook of Environment and Communication. New York. Routledge Press.

Boykoff, N. (2010). Indian media representations of climate change in a threatened journalistic ecosystem. Climatic Change, [Online] 99(I), I725Available from doi: 1007/s 10584-010-9807-8 [Accessed 12th January, 2017]

Boykoff, M. T. (20/3). Public enemy No.I? Understanding media representations of Outlier views on climate change. American Behavioral Scientist. 57(6),796-8I7

Boykoff, M. T. (2009). We speak for the trees: Media reporting on the environment. Annual Review of Economic Resources. 34(I), 431457.

Boykoff, M. T. (2007). From convergence to contention: United States mass media representations of anthropogenic climate change science. Transactions of the Institute of British Geographers, New Series, 32(4), 477-489

Boykoff, M. T. \& Boykoff, J. M. (2007). Climate change and journalistic norms: A case-study of US mass media coverage. Geoforum, 38(I), 11901204

Boykoff, M. T. \& Roberts, J. T. (2007). Media coverage of climate change: current trends, strengths, weaknesses. United Nations Development Programme. Human Development Report 2007. Background Paper Final version.

Centre for Research on Environmental Decisions, CRED, (2009). The Psychology of Climate Change Communication: A guide for Scientists, Journalists, Educators, Political aides and the interested Public. New York. Columbia University

Chetty, K., Devadas, V. \& Fleming, J. S. (20I5). The framing of climate change in New Zealand newspapers from June 2009 to June 2010. Journal of the Royal Society of New Zealand, [Online] 45(I), I-20. Available from http://dx.doi.org/I0.1080/03036758.2014.996223 4 [Accessed I2th January, 20I7]

Cramer, C. M. (2008). The Framing of Climate Change in three Daily Newspapers in the Western Cape province of South Africa. Being a Thesis Presented in Partial Fulfillment of the Requirements for a degree of Master of Philosophy (journalism) at Stellenbosch University. CSJ (20|6). Budgeting for Climate Change in Agriculture. Abuja. Centre for Social Justice.

De Blasio, E. \& Sorice, M. (20/3). The framing of climate change in Italian politics and its impact on public opinion. International Journal of Media \& Cultural Politics, [Online] 9(I), 59-69. Available from doi: 10.1386/macp.9.1.59_I [Accessed IIth June, 20I7]

DeVresse, C. H. (2005). News Framing: Theory and Typography. Information Design Journal \& Document Design. I3(I), 5I-62.

DeVresse, C. H. (2003). Framing Europe: Television news and European integration. $\mathrm{A} \mathrm{PhD}$ thesis submitted to the Amsterdam School of Communication Research, University of Amsterdam. [Online] Available from http://hdi.handle.net/ I I 245/2.48935 [Accessed IOth April, 2014]

Doulton, H. \& Brown, K. (2009). Ten years to prevent catastrophe? Discourses of climate change and international development in the UK Press. Global Environmental Change, 19(I), 191-202

GNA (20I8). Former President Kufuor launches Guidebook on Climate Change. Ghana News Agency, Government of Ghana. [Online]. Available from www.ghana.gov.gh/index.php/mediacenter/news/724-former-president-kufuorlauches-guidebook-on-climate-change [Accessed II th February, 20|8] 
Hallahan, k. (1999). Seven models of framing: Implications for Public Relations. Journal of Public Relations Research, II (3), 205-242.

Hoijer, B. (2010). Emotional anchoring and objectification in the media reporting on climate change. Public Understanding of Science, 19(6), 7|7-73|

Kalvas, F., Vane, J., Stipkova, M. \& Kredl, M. (20II). Framing and Agenda-Setting: Two Parallel Processes in Interaction. [Online] Available from http://wapor.unl.edu/wp-

content/uploads/201 I/09/kalvas_vane_stipkova_kr eidl.doc [Assessed I7th June, 20|4]

Littlejohn, S. W. \& Foss, K. A. (2008). Theories of Human Communication, Ninth Edition. Boston, USA. Wadsworth.

Lomborg, B. (20I5). What does the Paris treaty look like for Ghana. Daily Graphic, December, 10. P. 43

McEvoy, D., Funfgeld, H. \& Bosomworth, K. (20I3). Resilience and climate change adaptation: The importance of Framing. Planning Practice \& Research [Online] 28(3), 280-293. Available from doi: I0.1080/02697459.2013.7877| 0 [Assessed on 23rd June, 20I5]

McQuail, D. (2005). McQuail's Mass Communication Theory, Fifth Edition. Great Britain. Sage.

Mercado, M. T. (20/2). Media representations of climate change in the Argentinean press. Journalism Studies [Online] 13(2), 193-209 Available from doi: 10.1080/1461670x.20II.646397 [Assessed on 23rd June, 2015]

Nashuuta, L. (2016). Media Vital in the attainment of SDGs. Southern Times. [Online] Available from http://southernafrican.news/2016/06/19/mediavital-in-the-attainment-sdgs/ [Accessed 6th October, 2017]

Nwabueze, C. and Egbra, S. (20I6). Newspaper Framing of climate change in Nigeria and Ghana. Applied Environmental Education \& post-2015/sdg-overview/goal-13.html [Accessed I0th October, 2017]

Weathers, M. R. \& Kendall, B. E. (2015). Developments in the framing of climate change as a public health issue in US newspapers. Environmental Communication. [Online] Available from doi: 10.1080/17524032.2015.1050436 [Accessed I0th October, 2017]

WHO (2015a). Climate and Health Country ProfileGhana. [Online] Available from http://apps.who.int/iris/bitstream/l0665/208862/I WHO_FWC_PHE_EPE_15.08_eng.pdf [Accessed 24th February, 2018]
Communication, [Online]5(2), III-124. Available from doi: 10.1080/I5330I5x.2016.1I64094 [Accessed I 2th December, 20I7]

Odjugo, P. A. O. (20I0). General overview of climate change impacts in Nigeria. Journal of Human Ecology, 29(I), 47-55

Scheufele, D. A. \&Tewksbury, D. (2007). Framing, Agenda Setting and Priming: The Evolution of Three Media Effects Models. Journal of Communication. [Online] 57(I). Available from doi: 10.1 I I I/j. I460-2466.2006.00326.x [Accessed I5th April, 20|4]

Scheufele, D. A. (2000). Agenda-setting, priming and framing revisited: Another look at cognitive effects of political communication. Mass Communication \& Society, 3(2\&3), 297-316

Shehata, A. \& Hopmann, D. N. (20|2). Framing climate change. Journalism Studies, [Online] 13(2), 175-192. Available from doi: 10.1080/1461670x.20II.646396 [Accessed 10th June, 20I4]

Tagbo, E. (20I0). Media coverage of climate change in Africa: A case study of Nigeria and South Africa. Reuters Institute Fellowship Paper, UK, University of Oxford. [Online] Available from http://reutersinstitute.politics.ox.ac.uk/sites/defaul t/files [Accessed I2th December, 2017]

Takahashi, B. (20I I). Framing and sources: A study of mass media coverage of climate change in Peru during the VALCUE. Public Understanding of Science, [Online] 20(4), 543-557. Available from doi: I0.1 I 77/09636625093565502 [Accessed I0th June, 2014]

Ukonu, M. O., Akpan, C. S. \& Anorue, L. I. (20I2). Nigerian newspaper coverage of climate change, 2009-2010. New Media and Mass Communication, 5(I), 22-37

UNDP (n.d). Goal 13: Climate Action. [Online] Available from www.ng.undp.org/content/nigeria/en/home/

WHO (20I5b). Climate and Health Country ProfileNigeria. [Online] Available from http://apps.who.int/iris/bitstream// 0665/208865/I WHO_FWC_PHE_EPE_15.II_eng.pdf [Accessed 24th February, 20I8]

Wilmer, R. D. \& Dominick, J. R. (20I I). Mass Media Research. An Introduction. Canada. Wadsworth Cengage Learning.

Young, N. \& Dugas, E. (20I2). Comparing climate change coverage in Canadian English -and FrenchLanguage print media: Environmental values, media cultures and the narration of Global warming. The Canadian Journal of Sociology, vol. 37(I), pp. 25-54. 